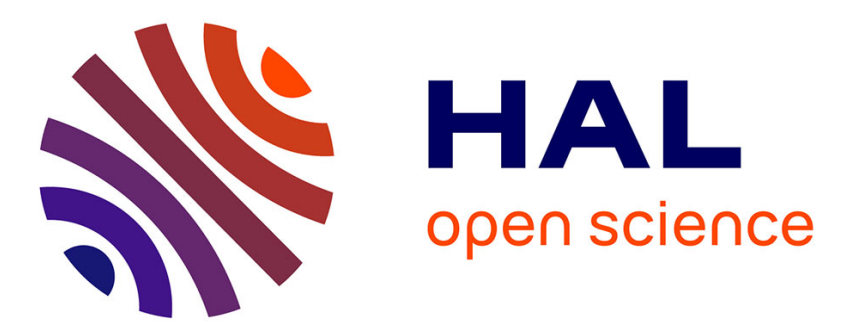

\title{
Uncertainty evaluation of ozone production and its sensitivity to emission changes over the Ile-de-France region during summer periods
}

\author{
Laurent Deguillaume, M. Beekmann, C. Derognat
}

\section{To cite this version:}

Laurent Deguillaume, M. Beekmann, C. Derognat. Uncertainty evaluation of ozone production and its sensitivity to emission changes over the Ile-de-France region during summer periods. Journal of Geophysical Research: Atmospheres, 2008, 113 (D2), pp.D02304. 10.1029/2007jd009081 . hal01998744

\author{
HAL Id: hal-01998744 \\ https://hal.uca.fr/hal-01998744
}

Submitted on 29 Jan 2019

HAL is a multi-disciplinary open access archive for the deposit and dissemination of scientific research documents, whether they are published or not. The documents may come from teaching and research institutions in France or abroad, or from public or private research centers.
L'archive ouverte pluridisciplinaire HAL, est destinée au dépôt et à la diffusion de documents scientifiques de niveau recherche, publiés ou non, émanant des établissements d'enseignement et de recherche français ou étrangers, des laboratoires publics ou privés. 


\title{
Uncertainty evaluation of ozone production and its sensitivity to emission changes over the Ile-de-France region during summer periods
}

\author{
L. Deguillaume, ${ }^{1}$ M. Beekmann, ${ }^{1}$ and C. Derognat ${ }^{2}$ \\ Received 19 June 2007; revised 10 September 2007; accepted 7 October 2007; published 19 January 2008.
}

[1] The approach of Bayesian Monte Carlo analysis has been used for evaluating model uncertainty in ozone production and its sensitivity to emission changes. This approach has been applied to the ozone fields calculated by the CHIMERE regional model in the Ile-de-France area during the 1998 and 1999 summer seasons. The AIRPARIF network measurements of urban $\mathrm{NO}$ and $\mathrm{O}_{3}$ concentrations and rural $\mathrm{O}_{3}$ over the Ile-de-France region have been used for constraining the Monte Carlo simulations. Our results yield the following major conclusions: (1) The simulated formation of $\mathrm{O}_{3}$ plumes are mainly located in southwestern to southeastern directions downwind the Paris area. (2) Uncertainties on simulated ozone concentrations and several derived quantities are evaluated and reduced using the BMC approach; simulated urban and plume ozone concentrations are enhanced through the observational constraint as compared to those obtained from the unconstrained model. (3) The chemical regime over the urban area of Paris and within plumes is clearly VOC sensitive on the average over two summers. This statement is robust with respect to the BMC uncertainty analysis.

Citation: Deguillaume, L., M. Beekmann, and C. Derognat (2008), Uncertainty evaluation of ozone production and its sensitivity to emission changes over the Ile-de-France region during summer periods, J. Geophys. Res., 113, D02304, doi:10.1029/2007JD009081.

\section{Introduction}

[2] Ozone is the most abundant photochemical oxidant and component of photochemical "smog," with wellknown deleterious effects on human health [Bascomb et al., 1996] as well as on vegetation [National Research Council, 1991]. Despite many years of efforts spent in controlling emissions which lead to photochemical ozone buildup, national ozone air quality thresholds are still frequently exceeded. For example, the European Community (EU) vegetation protection thresholds (in terms of AOT40, i.e., accumulated ozone levels above $40 \mathrm{ppb}$ ) is frequently exceeded over large areas especially over southern Europe [Tarasson et al., 2003]. The EU air quality information threshold of $180 \mu \mathrm{g} / \mathrm{m}^{3}$ has been for example exceeded during the summer 2003 heat wave over large parts of Western Europe [Vautard et al., 2005]. Ozone is a secondary pollutant formed in the troposphere through photochemical reactions involving nitrogen oxides (NOx) and volatile organic carbons (VOC). For air quality management issues, but also for fundamental understanding of chemical cycles, it is important to know whether ozone buildup is more sensitive to NOx or to VOC emission reductions. In the so-called "NOx sensitive chemical re-

\footnotetext{
${ }^{1}$ Laboratoire Inter-Universitaire des Systèmes Atmosphériques, UMR CNRS 7583, Universités Paris 7 et Paris 12, Créteil, France.

${ }^{2}$ Aria Technologies SA, Boulogne Billancourt, France.

Copyright 2008 by the American Geophysical Union. 0148-0227/08/2007JD009081
}

gime," NOx anthropogenic emission reductions are more efficient to reduce ozone levels than are VOC anthropogenic emission reductions [e.g., Sillman, 1999]. On the contrary, in the "VOC-sensitive regime," VOC emission reductions are more effective. Chemical regimes are intrinsically related to the dominance of different types of radical chain terminating reactions. A VOC sensitive chemical regime corresponds to a predominant radical loss pathway through the combination of $\mathrm{HOx}$ radicals $\left(\mathrm{HOx}=\mathrm{OH}+\mathrm{HO}_{2}+\mathrm{RO}_{2}\right)$ and NOx species [see Kleinman et al., 1997]. On the contrary, a larger sensitivity to NOx corresponds to a predominance of HOx radical recombination reactions.

[3] In order to describe and quantify the complex behavior of photochemical systems, one has to rely on 3D chemical transport models that simulate emissions, physical and chemical processes related to ozone formation, transport and dispersion and deposition in the (lower) troposphere. From this type of modeling studies, it has been shown (see the Sillman [1999] review), that the realization of a VOC or NOx sensitive chemical regimes depends on several forcings: (1) high ratios of VOC to NOx emissions favoring a NOx sensitive chemical regime; the presence of strong biogenic VOC emission sources can strongly enhance this ratio; (2) the accumulation of concentrations depending on emission intensity, wind speed and boundary layer height, favoring a VOC sensitive chemical regime; and (3) the actinic flux, more intense fluxes favoring a NOx sensitive chemical regime. Studies for evaluating the sensitivity of ozone buildup with respect to emission reductions have been performed in the past for a many urban areas, 
especially over Europe and the United States (Los Angeles [Roth et al., 1974; Reynolds et al., 1974], Atlanta [Sillman et al., 1995], Los Angeles [Sillman et al., 1997], Nashville [Sillman et al., 1998], New York [Kleinman et al., 2000], Leipzig [Klemm et al., 2000], Milan [Spirig et al., 2002], and Ile-de-France [Sillman et al., 2003]). These studies show that, in the city center, the chemical regime is often VOC sensitive, but sometimes also NOx sensitive as for Atlanta. The chemical regimes in the city plume were more variable from one urban area to the other, and also depend on the distance form the city centre. All these studies performed for specific and polluted events emphasize the day to day variability of the chemical regime and show that a more long-term oriented approach is needed for better characterizing the chemical regime. Moreover, the uncertainty in chemical regime calculations could not be addressed in most of these studies, at least not in a formal way.

[4] The present paper aims, for the first time, at solving both these important issues for a large urban area and its surroundings. The region chosen is Ile-de-France region (with the urban area of Paris in its center) totalizes a population of over 10 millions of habitants concentrated on a small area (around $12.000 \mathrm{~km}^{2}$ ) and is characterized by large anthropogenic emissions. The chemistry transport model CHIMERE [Vautard et al., 2000; Schmidt et al., 2001] will be applied for simulating ozone buildup in Ilede-France and in its plume. The chemical regime will be determined by simulating appropriate emission reduction scenarios. A formal method to assess the model uncertainty in simulation of photo-oxidant buildup and the chemical regime will be applied, Bayesian Monte Carlo (BMC) analysis [e.g., Bergin and Milford, 2000]. This method consists in performing a large number of simulations using, each time, different model input parameters (these parameters being chosen by chance from a fixed a priori distribution). The global (i.e., with respect to the whole set or perturbations) model uncertainty can then be analyzed from the model variability. Simulations which better fit observations receive a larger weight; that is, in Bayesian terms they have a larger conditional probability. In a previous study, the BMC method has been applied to three particular days during the ESQUIF campaign (Etude et Simulation de la Qualité de 1'Air en Ile-de-France [see Menut et al., 2000]) which took place in the Ile-de-France region in summers 1998 and 1999. A VOC sensitive regime has been found for two days, an intermediate regime for another day [Beekmann and Derognat, 2003]. Thus, in order to obtain a clearer picture of the average chemical regime and its variability, clearly longer-term simulations and the related uncertainty analysis are needed. The present paper aims at covering this need. The BMC this method is for the first time applied to chemical regime simulations over a large urban area and in its plume for an extended time period (two summer seasons).

[5] The paper is organized as follows: Section 2 is devoted to the model description; section 3 presents the setup of the Bayesian Monte Carlo analysis and introduces the methods used for ozone plume analysis over the Ile-deFrance region; results are presented in section 4: first, ozone buildup in the Paris area and plume, and its uncertainty, are presented, second the chemical regime (uncertainty) is addressed. A discussion is given in section 5, and conclusions in section 6 .

\section{Model Description}

[6] The Eulerian multiscale model CHIMERE is designed to produce daily forecasts of ozone over Western Europe and allows performing long-term simulations over several seasons. In the present study, a nested domain with $150 \mathrm{~km}$ horizontal extension and centered over Paris is used, with a horizontal grid resolution of $6 \mathrm{~km}$. The continental-scale version covering Western Europe with a $0.5^{\circ}$ horizontal resolution is used to provide boundary conditions for several long-lived species (ozone, NOy species, VOCs, $\mathrm{CO}$, peroxides, etc.) to the nested domain. In the vertical, eight layers defined by hybrid coordinates (that is, which mostly depend on surface pressure at ground, but relax to constant pressure near the model top) are used. The height of the first layer is fixed at $50 \mathrm{~m}$ high and follows the orography and the top of the upper layer is fixed by a constant pressure level of $500 \mathrm{hPa}$.

[7] For the present study, CHIMERE is forced by first guess meteorological fields delivered all $6 \mathrm{~h}$ by ECMWF (European Centre for Medium Range Weather Forecast), with a spectral resolution of T319. Vertical diffusion is calculated using the parameterization given by Troen and Mahrt [1986].

[8] The gas phase chemical reaction scheme MELCHIOR (Modele Lagrangien de Chimie de l'Ozone a l'échelle Régionale) [Schmidt et al., 2001], adapted from the EMEP (European Monitoring and Evaluation Program) scheme [Simpson et al., 1993; Simpson, 1995], describes in its reduced version more than 110 reactions of 40 gaseous species. Photolysis rates are calculated using the tabulated outputs from the TUV model from Madronich and Flocke [1998] (Tropospheric Ultraviolet and Visible model), depending on altitude, zenithal angle and cloud cover.

[9] The anthropogenic $\mathrm{NOx}, \mathrm{VOC}, \mathrm{CO}$ and $\mathrm{SO}_{2}$ emissions for the Ile-de-France region and the year 1997 have been prepared by AIRPARIF and are described in detail by Vautard et al. [2003]. They were calculated for three types of days (weekday, Saturday and Sunday) with a $1 \mathrm{~h}$ temporal and a three kilometers spatial resolution. The biogenic emissions (isoprene and terpene, NO) inventory is described by Derognat et al. [2003].

[10] The numerical method for solution of the stiff system of partial differential equations governing the model is adapted from the second-order two-step algorithm [Verwer, 1994]. A more detailed description of basic features of earlier model versions can be found in the papers from Schmidt et al. [2001] and Vautard et al. [2000]. A comprehensive scientific and technical documentation and the source codes are also available on the Web (see http:// euler.lmd.polytechnique.fr/chimere/).

\section{Methodology}

[11] In this paper, we perform direct simulations with the CHIMERE Model for the two summer periods in 1998 and 1999 (July and August) in order to characterize the ozone production and its dependence on emission reductions over the Ile-de-France region for a seasonal-scale time period. In 


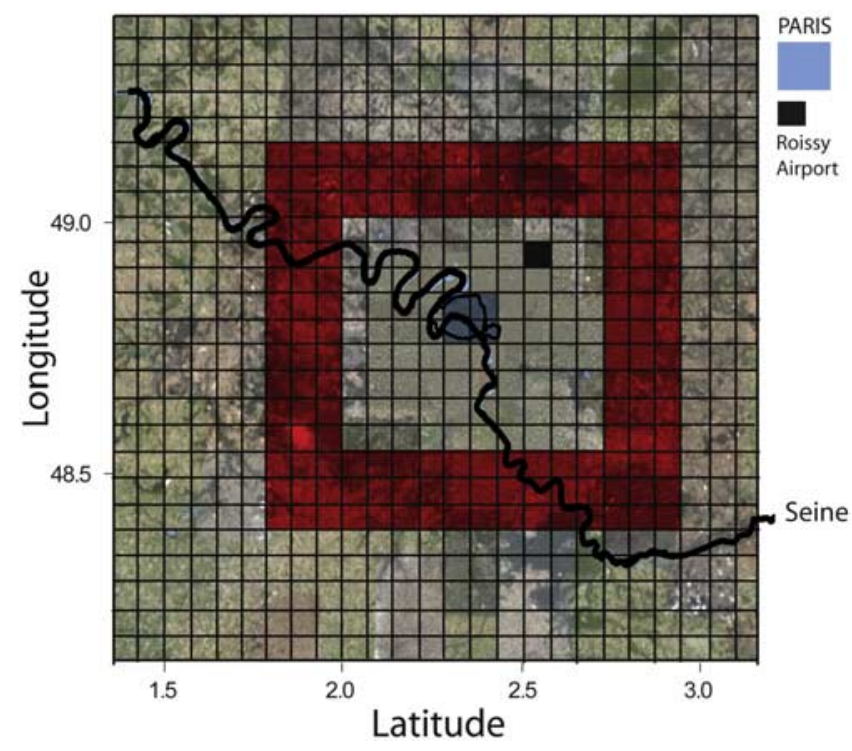

Figure 1. Localization of the grid cells (in red) used for calculation of the $\mathrm{O}_{3}$ background over the Ile-de-France region.

the following, we will use the term "reference model" for CHIMERE simulations using an unperturbed input data set (section 3.1). In addition, the Bayesian Monte Carlo analysis offers the possibility for a global uncertainty analysis while taking into account constraints by the observations on model parameters and variables and the setup of the method will be explained in section 3.2. When applying this method to appropriate emission reduction scenarios, it allows evaluating the uncertainty in the model sensitivity to emissions changes and thus the uncertainty in the chemical regime.

\subsection{Simulation With the Reference Model}

[12] In the present study, we analyze the temporal and spatial evolution of the $\mathrm{O}_{3}$ concentrations over the Paris region for the summer periods with the objective to characterize the $\mathrm{O}_{3}$ production in the plume and in the urban area. To this purpose, three ozone indicators are extracted from the simulations for further analysis. Only afternoon values (1200-1800 UTC) when the daily maximum generally occurs are considered: (1) daily maximum of $\mathrm{O}_{3}$ concentrations (三O3AbsMax) over the whole domain, (2) daily maximum of $\mathrm{O}_{3}$ concentrations over the Paris city (corresponding to 4 model grid cells marked on Figure 1) (三O3MaxParis), and (3) daily $\mathrm{O}_{3}$ maximum concentration averaged over the 60 grid cells with the most elevated $\mathrm{O}_{3}$ values. They represent around $10 \%$ of the surface of the total domain (三O3Max 10\%) and correspond roughly to the area covered by a typical ozone plume (i.e., in general, the largest ozone values appear downwind of the urban area). The use of three ozone indicators contributes to the characterization of the day to day variability of ozone formation during the summers 1998 and 1999.

[13] For characterizing the spatial ozone distribution and the average location of ozone plumes, we represent the distribution of the daily maximum of ozone $\left(\mathrm{MaxO}_{3}\right)$ over the Ile-de-France domain averaged over the whole time period (summers 1998 and 1999). In the same way, we also present the ozone production $\left(\mathrm{PO}_{3}\right)$ in the urban plume, by subtracting the calculated $\mathrm{O}_{3}$ background concentrations. Background ozone concentrations are calculated by averaging the quarter of lowest ozone values in a belt of grid cells around the Paris area average (Figure 1). The location of the belt is chosen in a rural area in vicinity of the urbanized area. Ozone values averaged from 1000 to 1300 UTC are extracted from the second model layer $(50-150 \mathrm{~m})$ since they are more representative of the average ozone value of the boundary layer than are surface values. Then, daily values are averaged over the whole time period ( 2 summers). Finally, we build map of a exceedance hours of the $90 \mathrm{ppb}$ air quality information threshold (EXCEED_90ppb). This map will give us an idea on the potential health impact of the ozone plume.

\subsection{Bayesian Monte Carlo Analysis}

[14] The BMC analysis is set up here in order to perform a formal uncertainty analysis of the photochemical ozone buildup and on chemical regimes. The analysis scheme in this work builds on the work of Beekmann and Derognat [2003] where uncertainty analysis was performed for three case studies. Parts of the methodology are similar to that used in the work of Deguillaume et al. [2007] for summers 1998 and 1999. Nevertheless the aim of this study was completely different from that of the present study, namely to retrieve anthropogenic $\mathrm{NOx}$ and $\mathrm{VOC}$ emissions in the Ile-de-France region. A general description of the BMC method will be presented hereafter.

\subsubsection{Formulation}

[15] The Monte Carlo approach consists in performing a large number of simulations with different sets of randomly perturbed model input parameters. Perturbations are randomly selection from predefined probability density functions. An extension of the standard Monte Carlo analysis called "Bayesian Monte Carlo" analysis consists in introducing a forcing by the observations: it allows giving a weight or probability to individual Monte Carlo simulations, depending on agreement between model output and observations.

[16] This method consists in evaluating the conditional probability term $\mathrm{p}\left(\mathbf{O} \mid \mathbf{Y}_{\mathbf{k}}\right)$ which indicates the probability to observe a vector $\mathbf{O}$ for a set of species concentrations, given that the model output $\mathrm{Y}_{\mathrm{k}}$ is the true value ( $\mathrm{k}$ being the index of an individual Monte Carlo simulation). For the case of $\mathrm{N}$ independent observations $\mathrm{O}_{\mathrm{j}}$, elements of the vector of observation $\mathbf{O}$, the agreement function $\mathrm{p}\left(\mathbf{O} \mid \mathbf{Y}_{\mathbf{k}}\right)$ can be evaluated as:

$$
\mathrm{p}\left(\mathbf{O} \mid \mathbf{Y}_{\mathbf{k}}\right)=\prod_{\mathrm{j}=1, \mathrm{~N}}\left(\frac{1}{\sqrt{2 \pi}} \frac{1}{\sigma_{\varepsilon, \mathrm{j}}} \times \exp \left(-0.5\left[\frac{\mathrm{O}_{\mathrm{j}}-\mathrm{Y}_{\mathrm{k}, \mathrm{j}}}{\sigma_{\varepsilon, \mathrm{j}}}\right]^{2}\right)\right)
$$

[17] For that, we assume that the observations are unbiased and present a normally distributed error $\varepsilon$. The errors or uncertainties $\sigma_{\varepsilon, \mathrm{j}}$ in observations have to be estimated and depend both on a purely experimental error and on the fact that point measurements are not necessarily representative for simulated averages over a model grid cell [Bergin and Milford, 2000]. These uncertainties are estimated in section 3.2.4. 
Table 1. Uncertainty Ranges Adopted for Model Input Parameters

\begin{tabular}{|c|c|}
\hline Parameters & $1 \sigma$ Uncertainty \\
\hline \multicolumn{2}{|c|}{ Emissions } \\
\hline Anthropogenic VOC & $\pm 40 \%$ \\
\hline Anthropogenic NOx & $\pm 40 \%$ \\
\hline Biogenic VOC & $\pm 50 \%$ \\
\hline \multicolumn{2}{|c|}{ Rate Constants } \\
\hline $\mathrm{NO}+\mathrm{O}_{3}$ & $\pm 10 \%$ \\
\hline $\mathrm{NO}_{2}+\mathrm{OH}$ & $\pm 10 \%$ \\
\hline $\mathrm{NO}+\mathrm{HO}_{2}$ & $\pm 10 \%$ \\
\hline $\mathrm{NO}+\mathrm{RO}_{2}$ & $\pm 30 \%$ \\
\hline $\mathrm{HO}_{2}+\mathrm{HO}_{2}$ & $\pm 10 \%$ \\
\hline $\mathrm{RO}_{2}+\mathrm{HO}_{2}$ & $\pm 30 \%$ \\
\hline $\mathrm{RH}+\mathrm{OH}$ & $\pm 10 \%$ \\
\hline $\mathrm{CH}_{3} \mathrm{COO}_{2}+\mathrm{NO}$ & $\pm 20 \%$ \\
\hline $\mathrm{CH}_{3} \mathrm{COO}_{2}+\mathrm{NO}_{2}$ & $\pm 20 \%$ \\
\hline $\mathrm{PAN}+\mathrm{M}$ & $\pm 30 \%$ \\
\hline \multicolumn{2}{|c|}{ Photolysis Frequencies and Radiation } \\
\hline Actinic fluxes & $\pm 10 \%$ \\
\hline $\mathrm{J}\left(\mathrm{O}_{3} \rightarrow 2 \mathrm{OH}\right)$ & $\pm 30 \%$ \\
\hline $\mathrm{J}\left(\mathrm{NO}_{2} \rightarrow \mathrm{NO}+\mathrm{O}_{3}\right)$ & $\pm 20 \%$ \\
\hline $\mathrm{J}\left(\mathrm{CH}_{2} \mathrm{O} \rightarrow \mathrm{CO}+2 \mathrm{HO}_{2}\right)$ & $\pm 40 \%$ \\
\hline $\mathrm{J}\left(\mathrm{CH}_{3} \mathrm{COCO} \rightarrow \ldots\right)$ & $\pm 50 \%$ \\
\hline $\mathrm{J}($ unsaturated carbonyl $\rightarrow \ldots$ ) & $\pm 40 \%$ \\
\hline \multicolumn{2}{|c|}{ Meteorological Parameters } \\
\hline Zonal wind speed & $\pm 1 \mathrm{~m} / \mathrm{s}$ \\
\hline Meridional wind speed & $\pm 1 \mathrm{~m} / \mathrm{s}$ \\
\hline Mixing layer height & $\pm 40 \%$ \\
\hline Temperature & $\pm 1.5 \mathrm{~K}$ \\
\hline Relative humidity & $\pm 20 \%$ \\
\hline Vertical mixing coefficient & $\pm 50 \%$ \\
\hline \multicolumn{2}{|c|}{ Others } \\
\hline Deposition velocity & \pm 25 \\
\hline
\end{tabular}

[18] In this study, the systematic uncertainty in model results is evaluated and not the uncertainty related to day to day variability. Systematic uncertainty means here uncertainty related to the time average of a model output variable over the simulation period. Correspondingly, the terms $\mathrm{O}, \mathrm{Y}$ and $\sigma$ in equation (1) represent temporal averages over the simulation period. Perturbation factors for input parameters correspond to the systematic uncertainty in these parameters, one single factor per input data type is applied over the whole time period of the simulation and also over the whole model domain. No sufficient information about random errors (i.e., varying from one day to another) in model input parameters was available in order to conduct a specific study about the uncertainty in the simulations day to day variability. Temporally averaging observations and simulations have also the advantage of reducing the representativity error in measurements (see 3.2.4).

\subsubsection{A Priori Probability Density Functions (PDFs) for Input Parameters}

[19] Input parameters such as emissions, rate coefficients of chemical reactions and photolysis frequencies, and meteorological parameters are randomly and simultaneously perturbed in order to perform Monte Carlo simulations. A priori probability density functions for these input parameters are considered as lognormal distribution and are summarized in Table 1. The choice of uncertainty ranges has been guided by uncertainty assessment studies found in the literature for emissions, rate coefficients, photolytic fre- quencies and deposition velocity [Beekmann and Derognat, 2003]. A priori uncertainty ranges of meteorological parameters are derived from comparisons with meteorological observations obtained during the ESQUIF campaign in the urban area of Paris, i.e., lidar measurements for boundary layer height determination [Beekmann and Derognat, 2003]. Note that errors in parameters are considered as independent. This is a necessary simplification of the method, because it is impossible to estimate error covariances with enough certainty.

\subsubsection{Measurement Constraints}

[20] The measurements used for constraining perturbed Monte Carlo simulations are chosen to contain as much as possible information for precisely characterizing the ozone buildup over the Ile-de-France region. All observations are extracted from routine measurements form the AIRPARIF air quality network. The observation vector $\mathbf{O}$ in equation (1) is built from 3 different types of observations: besides urban ozone measurements within (6 sites) and outside (6 sites) the urban area, also NO measurements within the urban area are taken into account, because they contain direct information on NOx emissions [Deguillaume et al., 2007]. Urban $\mathrm{O}_{3}$ and $\mathrm{NO}$ measurements are averaged overt the 6 urban sites in order to obtain spatially more representative values. Urban NO measurements are then temporally averaged over 0300 to 0900 UTC for each day (to integrate over the morning NO peak). Urban $\mathrm{O} 3$ was averaged over the afternoon peak period (1200-1600 UTC). For the 6 rural sites located at similar distance from Paris and covering the different directions, the daily $\mathrm{O}_{3}$ maximum of each station is extracted for each day and for both observations and simulations. Then, the $\mathrm{O}_{3}$ production in the plume is calculated as the difference from the two largest (considered as within the plume) and the three lowest values (considered as background). The choice of the plume and background sites for each day can be different in simulations and observations allowing for errors in the simulated plume direction. As mentioned before, all these daily observations and simulations are finally averaged over the whole time period (4 months).

\subsubsection{Uncertainty in Observations}

[21] The BMC analysis requires the knowledge of the uncertainties in observations $\sigma_{\varepsilon, \mathrm{j}}$ in equation (1). For this, instrumental uncertainties, horizontal and vertical representativity have to be evaluated. Then, the instrumental error $\sigma_{\mathrm{i}}$, to the horizontal representativity $\sigma_{\mathrm{h}}$ and to the vertical representativity $\sigma_{\mathrm{v}}$ are combined to the overall variances $\sigma^{2}$ :

$$
\sigma^{2}=\sigma_{\mathrm{i}}^{2}+\sigma_{\mathrm{h}}^{2}+\sigma_{\mathrm{v}}^{2}
$$

[22] Note that the subscript $\mathrm{j}$ for different types of observations has been omitted for simplicity. Table 2 summarizes $1 \sigma$ logarithmic total uncertainties obtained

Table 2. One- $\sigma$ Logarithmic Errors for Measurement Constraints and for Summers 1998 and 1999 (July and August)

\begin{tabular}{lcc}
\hline Measurement Constraints & Period & One- $\sigma$ Logarithmic Errors \\
\hline $\mathrm{O}_{3}{ }^{\text {plume }}-\mathrm{O}_{3}{ }^{\text {background }}$ & $1998+1999$ & 0.266 \\
Urban $\mathrm{NO}$ & $1998+1999$ & 0.308 \\
Urban $\mathrm{O}_{3}$ & $1998+1999$ & 0.137 \\
\hline
\end{tabular}




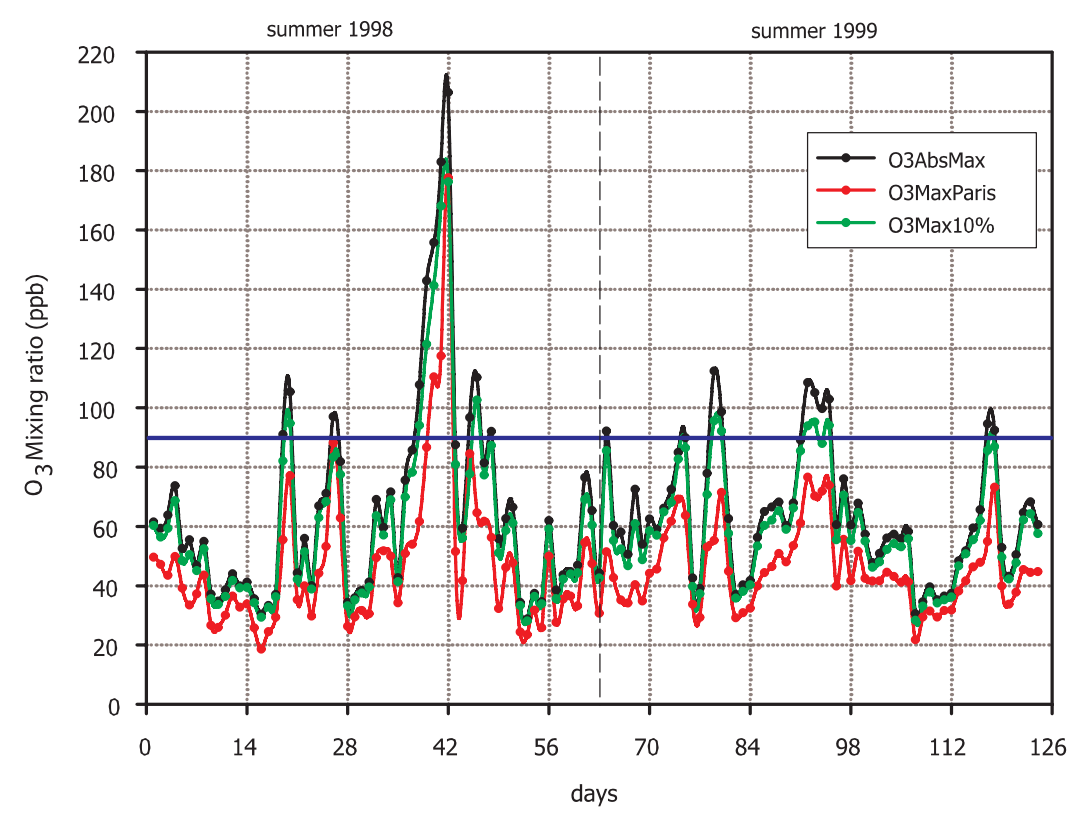

Figure 2. Absolute maximum of ozone (O3AbsMax), maximum of $\mathrm{O}_{3}$ in Paris (O3MaxParis), and 60 most elevated values of $\mathrm{O}_{3}$ grid cells (O3Max10\%) for individual days of the July-August 1998 and 1999 period.

for the four months average. These uncertainties are calculated from published instrument uncertainties; horizontal representativity errors are calculated from the standard deviation of the spatial averages. The calculation of total uncertainties is presented in more detail by Deguillaume et al. [2007].

\subsubsection{Practical Setup and Types of Results}

[23] The present work builds on the 500 perturbed Monte Carlo simulations previously performed by Deguillaume et al. [2007] for use of inverse emission modeling. Here the simulations are used for a completely different purpose, i.e., uncertainty analysis in the regional ozone buildup. The a posteriori weight (calculated for each Monte Carlo simulation as explained above) was applied to model output and especially to simulated ozone fields. Results from this BMC analysis are presented as cumulative probability density functions (CPDFs). $\mathrm{CPDF}(\mathrm{X})$ indicates the probability that a given model prediction $\mathrm{X}_{\mathrm{k}}$ stays below a certain limit $\mathrm{X}$. $\mathrm{X}_{\mathrm{k}}$ can represent any model output variables, for example the ozone concentration at a particular grid point. The comparison between Bayesian and simple Monte Carlo analysis allows assessing the reduction in model uncertainty by using observations.

[24] For the set of the 100 most probable Monte Carlo simulations (covering 93\% of the total probability), additional simulations of emission reduction scenarios were performed (either NOx or VOC anthropogenic emissions reduced by $30 \%$ with respect to baseline emissions). Note that when doing this, for each Monte Carlo simulation with already perturbed emissions, an additional change, corresponding to the emission scenario is applied. The number of simulations for the scenario calculations was limited to 100 for the sake of reducing computer PCU time. This does not induce any significant bias in the results. In fact, there is practically no difference in the CPDF shapes obtained with 100 constrained Monte Carlo simulations to those obtained by performing 500 simulations of baseline emissions.

\section{Results}

\subsection{Characterization of the Paris Plume for Two} Summer Periods

[25] In this part, the description of the photo-oxidant plume in the Ile-de-France region based on CHIMERE simulations for the summers 1998 and 1999 (July and August) is presented. Results are averaged over the two summer periods in order to increase representativity. In any case, major results are robust regardless of which summer is chosen. Several aspects of the ozone plume are analyzed: its favorite location, maximum ozone levels, local ozone production versus advection and exceedance of air quality threshold limits. We first present results with the reference model, and then perform uncertainty analysis using the Bayesian Monte Carlo formalism.

\subsubsection{Reference Model}

4.1.1.1. Characterization of the Temporal Variability of Ozone With the CHIMERE Model

[26] Figure 2 represents the time evolution of the absolute maximum of ozone (O3AbsMax), the maximum of $\mathrm{O}_{3}$ in Paris (O3MaxParis) and the plume average (O3Max10\%) for the 124 days of simulation (see in section 3.1 for a definition of these quantities). We first notice that the absolute maximum of ozone is always located outside the Paris urban region, as $\mathrm{O}_{3} \mathrm{AbsMax}$ is always larger than $\mathrm{O}_{3}$ MaxParis. Second, we observe a very strong ozone episode during August 1998 (days 39 to 42 of the considered time period) with $\mathrm{O}_{3}$ AbsMax values varying between 140 to $210 \mathrm{ppb}$. This episode corresponds to the ESQUIF IOP 2 during which high temperatures (daily surface maximum above $35^{\circ} \mathrm{C}$ ) and low wind speeds (below $3 \mathrm{~m} / \mathrm{s}$ ) 

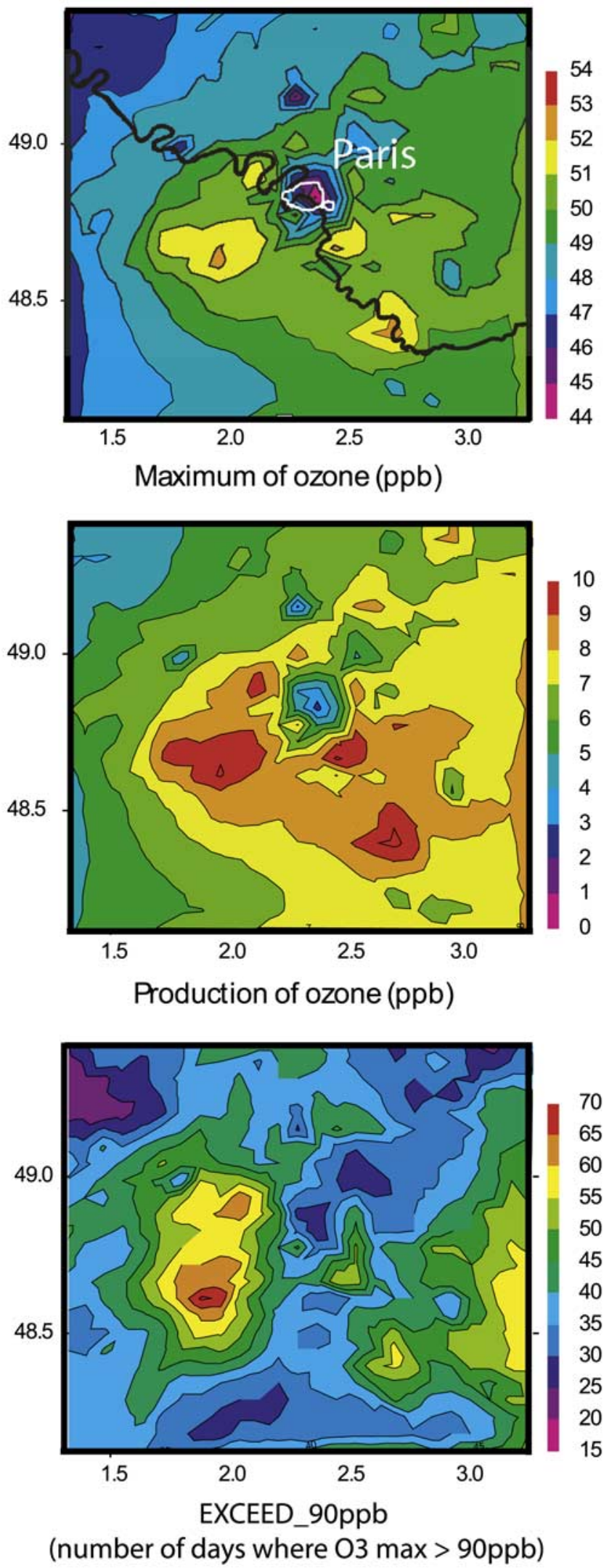

Figure 3. Reference simulations averaged over summers 1998 and 1999 (daily ozone maximum, local ozone production, and EXCEED_90ppb criterion). prevailed [Menut et al., 2000]. However, ozone maxima above $90 \mathrm{ppb}$, therefore exceeding the European and French air quality information (what is information here?) threshold, were not restricted to this particular period. Indeed, during the summers 1998 and 1999, 18 days displayed ozone plume concentrations above $90 \mathrm{ppb}$.

\subsubsection{Characterization of the Spatial Variability of Ozone With the CHIMERE Model}

[27] We next evaluate the simulated spatial ozone distribution averaged over the two considered summers. We build maps for the daily maximum of ozone, for local ozone production and for the EXCEED 90ppb criterion corresponding to the number of hours where the $\mathrm{O}_{3}$ concentration exceeds $90 \mathrm{ppb}$ (Figure 3). First, we notice a general west-east gradient in averaged daily ozone maxima, due to prevailing westerly to southwesterly winds [Derognat, 2002]: clean oceanic air masses are advected to the Paris area and subsequent ozone buildup occurs within the plume in the eastern sector of Paris. Superimposed on this feature we identify several cells with enhanced ozone values (between 51 and $53 \mathrm{ppb}$ ) occurring in a southwestern to southeastern direction downwind of Paris. The cell in southwesterly direction is due to less frequent but more intense plumes, occurring under anticyclonic conditions with weak northwesterly winds. The average daily ozone production for the two summers was around $10 \mathrm{ppb}$ at several tens of $\mathrm{km}$ from the Paris center and decreased at larger distances. Within the urban area, the average ozone production was below $5 \mathrm{ppb}$. In interpreting these results, we have to keep in mind that Figure 3 has been constructed irrespective of the fact that the plume was present or not. Therefore the average daily ozone buildup of about $10 \mathrm{ppb}$ is smaller than average buildup within the plume. Besides, the spatial structure of the daily maximum ozone concentration and the daily ozone production map is identical (Figure 3), because a single daily ozone background value is calculated for the whole domain for each day.

[28] Finally, the EXCEED_90ppb criterion emphasizes again the picture of two distinctive "high ozone" cells (values between 50 and $70 \mathrm{~h}$ ), one occurring in western to southwestern direction from the urban area, the other in eastern direction. However, values in the western cell are much larger; this illustrates again the fact that major pollution events are often related to northeasterly winds. During these events, not only the ozone production within the model domain is enhanced, but also advection from outside, because continental air masses are transported into the domain. The larger distance of the easterly cell from the urban area (near the eastern model edge and probably beyond) is due to a more continuous ozone production under stronger prevailing westerly winds.

\subsubsection{Bayesian Monte Carlo Approach}

[29] In this section, the BMC method presented in section 3.2 is applied to obtain probabilistic statements about the ozone production in the Ile-de-France region. This would allow us to assess the uncertainty affecting the results obtained with the references model as presented in section 4.1.1. As previously said, 500 Monte Carlo simulations have been performed for summers 1998 and 1999. From these simulations, we draw cumulative probability density functions (CPDFs) (Figure 4) for the three ozone diagnostics $\left(\mathrm{O}_{3}\right.$ AbsMax, $\mathrm{O}_{3}$ Max $10 \%, \mathrm{O}_{3}$ MaxParis $)$ aver- 




Figure 4. Cumulative probability density function (CPDF) for Monte Carlo simulations without constraints ("no") and constrained by observations ("constraints") averaged over summers 1998 and 1999. Red indicates daily absolute maximum of ozone over the model domain (O3AbsMax), green indicates daily maximum of ozone in the Paris area (O3MaxParis), and blue indicates average of the 60 grid cells with the most elevated daily ozone maxima (O3Max10\%, intended to reflect the plume average).

aged over the simulation period, for which we determine the 10th, 50th and 90th percentiles. CPDFs for the unconstrained Monte Carlo ("MC") simulations and those constrained by observations ("BMC") are distinguished (see Table 3).

[30] Applying observational constraints has the effect of reducing the uncertainty range spanned by the 10th and 90th percentiles (by a factor of 1.6 for O3AbsMax, 1.83 for O3MaxParis and 1.7 for O3Max 10\%). CPDFs become more point symmetrical, because the probability of reaching elevated ozone values is reduced (Figure 4). Values of the 50th percentiles are increased by several ppbs when applying observational constraints, indicating that ozone production is somewhat underestimated in the reference model.

[31] Figure 5 represents the spatial structure of the simulated 50th percentile for ozone production and the EXCEED_90ppb indicator, averaged for the whole time period, again for the $\mathrm{MC}$ and the BMC approach. Overall, the constrained and unconstrained Monte Carlo simulations display a similar spatial structure when compared to the reference model in the two preferential directions of the ozone plume (southwest and southeast). As noted above, ozone production is globally enhanced when constraints are applied. The increase is around $4 \mathrm{ppb}$ in the Paris area, around $5 \mathrm{ppb}$ in the surroundings (where the urban plume appears), but small $(<1 \mathrm{ppb})$ near the edges of the model domain. For the EXCEED 90ppb indicator, the constraint induces the largest increase for grid cells, for which unconstrained values are already large (around $10 \mathrm{~h}$ more in the west of Paris).

[32] Nearly no increase is observed in the cell near the easterly model edge. These increases are related to the way the constraints act on the system. Indeed, Deguillaume et al. [2007] showed that observational constraint gives larger weight to model configurations with enhanced VOC emissions, because they better agree with observed urban ozone concentrations and ozone production rate in the plume [see Deguillaume et al., 2007, Table 3b]. Enhanced VOC emissions will act on ozone concentrations especially in regions where the chemical regime is VOC sensitive, that is within the urban area and up to several tens $\mathrm{km}$ of distance (see below).

[33] Figure 6 represents the 10th and 90th percentile of the BMC experiment for the $\mathrm{O}_{3}$ production and the EXCEED 90ppb indicator. Again, the difference between those two percentiles can be taken as an evaluation of the

Table 3. The 50th, 10th, and 90th Percentiles for O3AbsMax, O3MaxParis, and O3Max10\% Averaged Over Summers 1998 and 1999 From Constrained or Unconstrained Monte Carlo Simulations

\begin{tabular}{|c|c|c|c|c|c|c|c|c|c|}
\hline & \multirow[b]{2}{*}{ Reference } & \multicolumn{2}{|c|}{$\mathrm{P} 50$} & \multicolumn{2}{|c|}{ P10 } & \multicolumn{2}{|c|}{$\mathrm{P90}$} & \multicolumn{2}{|c|}{ P90-P10 } \\
\hline & & $\begin{array}{l}\text { Without } \\
\text { Constraint }\end{array}$ & $\begin{array}{c}\text { Total } \\
\text { Constraint }\end{array}$ & $\begin{array}{c}\text { Without } \\
\text { Constraint }\end{array}$ & $\begin{array}{c}\text { Total } \\
\text { Constraint }\end{array}$ & $\begin{array}{c}\text { Without } \\
\text { Constraint }\end{array}$ & $\begin{array}{c}\text { Total } \\
\text { Constraint }\end{array}$ & $\begin{array}{c}\text { Without } \\
\text { Constraint }\end{array}$ & $\begin{array}{c}\text { Total } \\
\text { Constraint }\end{array}$ \\
\hline O3AbsMax & 65.5 & 64.1 & 71.5 & 54.1 & 64.2 & 84.4 & 84 & 30.3 & 19.8 \\
\hline O3MaxParis & 46.7 & 47.2 & 50.9 & 35.1 & 45.8 & 60.6 & 58.7 & 23.6 & 12.9 \\
\hline O3Max $10 \%$ & 59.9 & 59.7 & 65.8 & 50.3 & 60 & 74.7 & 74.3 & 24.4 & 14.3 \\
\hline
\end{tabular}




\section{MONTE CARLO}
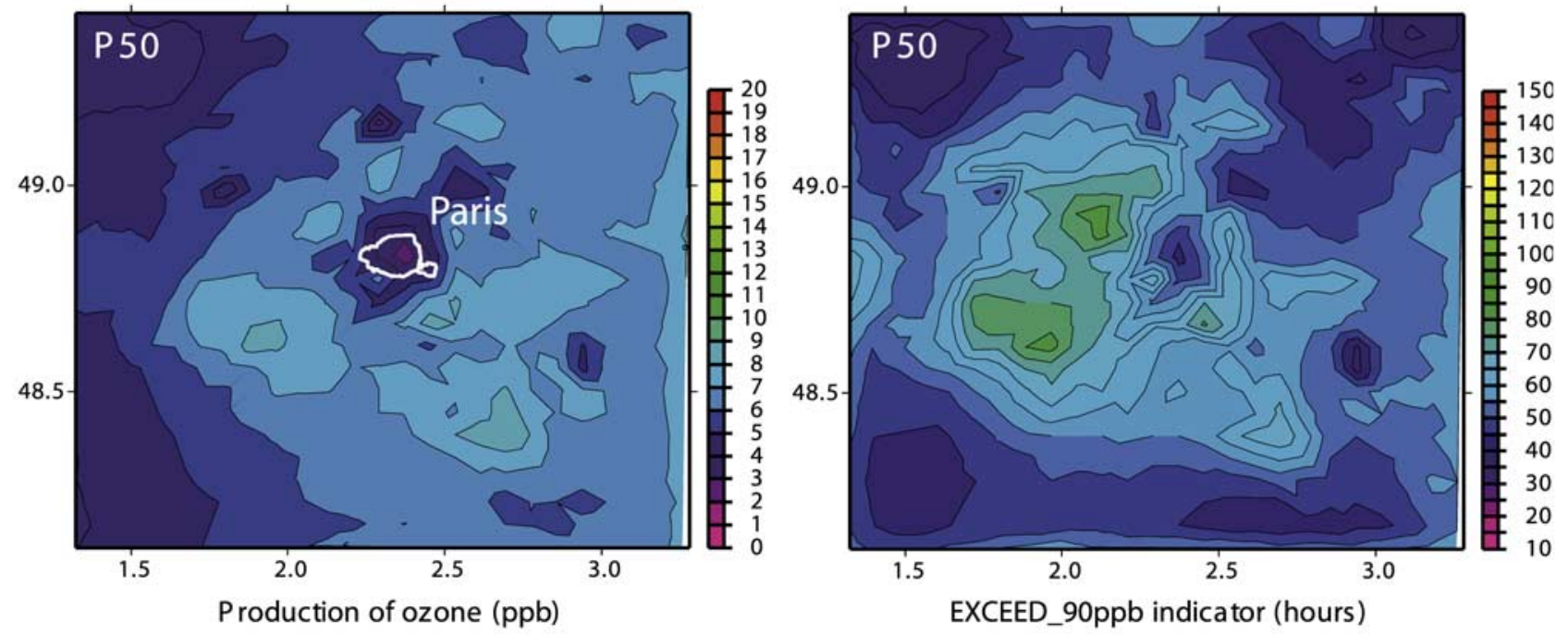

BAYESIAN MONTE CARLO
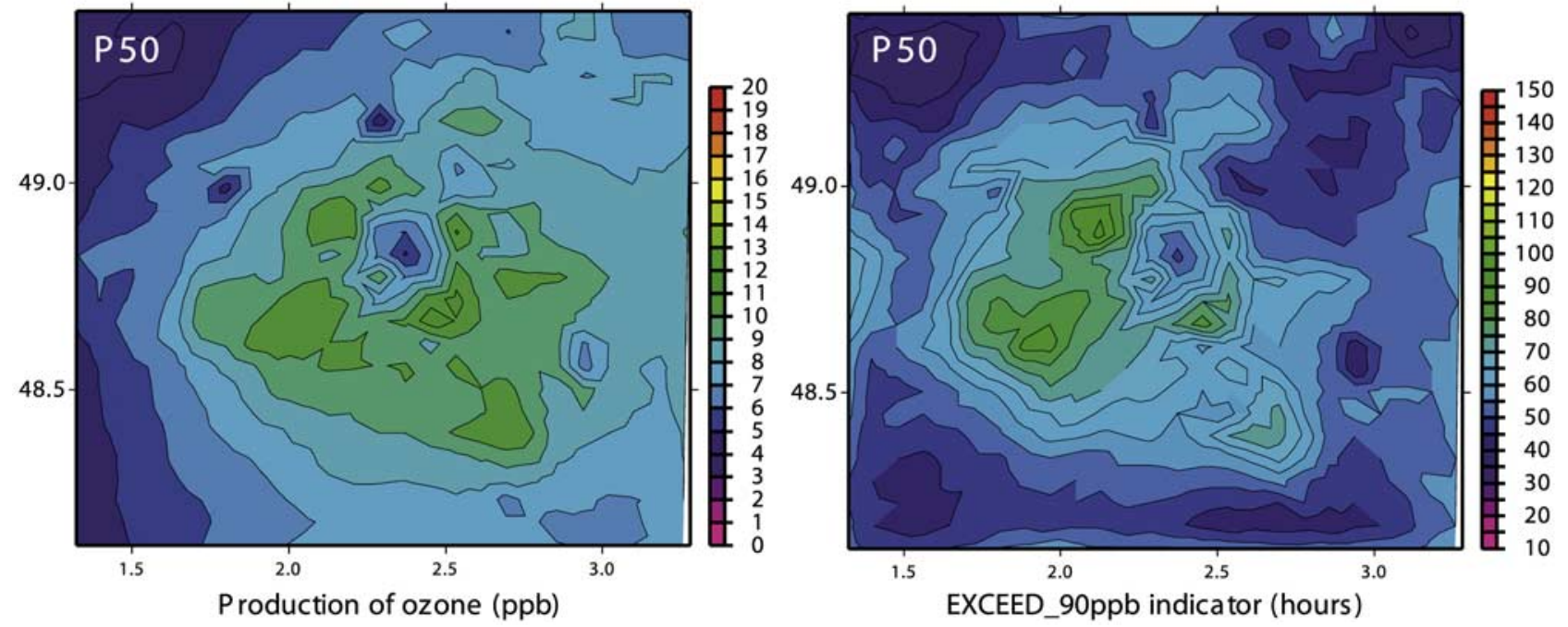

Figure 5. Simulated 50th percentile of the local ozone production and the EXCEED 90ppb indicator averaged or cumulated over summers 1998 and 1999 from (top) constrained or (bottom) unconstrained Monte Carlo simulations.

model uncertainty. To the west of the Paris area, where EXCEED_90ppb indicator is highest, values range from around $50-70 \mathrm{~h}$ for the 10 th percentile to around $110-140 \mathrm{~h}$ for the 90th percentile. Thus uncertainty in this important air quality management indicator is roughly a factor of two in this area, and even larger in other areas where, conversely, the absolute values are lower. Correspondingly, for areas where the ozone production is highest, that is, to the southwest and southeast of Paris, its uncertainty is roughly a factor of two (7-9 ppb for the 10th and 15-17 ppb for the 90th percentile). It also can be noted that these uncertainties have been significantly reduced by applying the observational constraint.

[34] In conclusion, BMC analysis shows that (1) ozone values in and outside the urban area are increased through the observational constraint, compared to the reference model and (2) the structure of the ozone fields is similar.
Finally, this method allows evaluating uncertainties in the simulated $\mathrm{O}_{3}$ concentrations and derived indicators.

\subsection{Chemical Regime Over the Ile-de-France Region}

[35] In this section, we present simulations obtained by reducing of $30 \%$ either the NOx or the VOC anthropogenic emissions. By doing so, we study the average spatial structure and temporal variability of the chemical regime in and around the Paris area. Again, we first present results obtained with the reference model, and then the uncertainty analysis performed using the BMC method.

\subsubsection{Reference Model With the Reduced Emission Scenarios}

[36] We first analyze the temporal variability of the model response to anthropogenic emission reductions. Figure 7 represents the difference in the ozone diagnostics $\left(\mathrm{O}_{3} \mathrm{AbsMax}\right.$, $\mathrm{O}_{3} \mathrm{Max}$ Paris and $\mathrm{O}_{3} \mathrm{Max} 10 \%$ ) between the reference simu- 

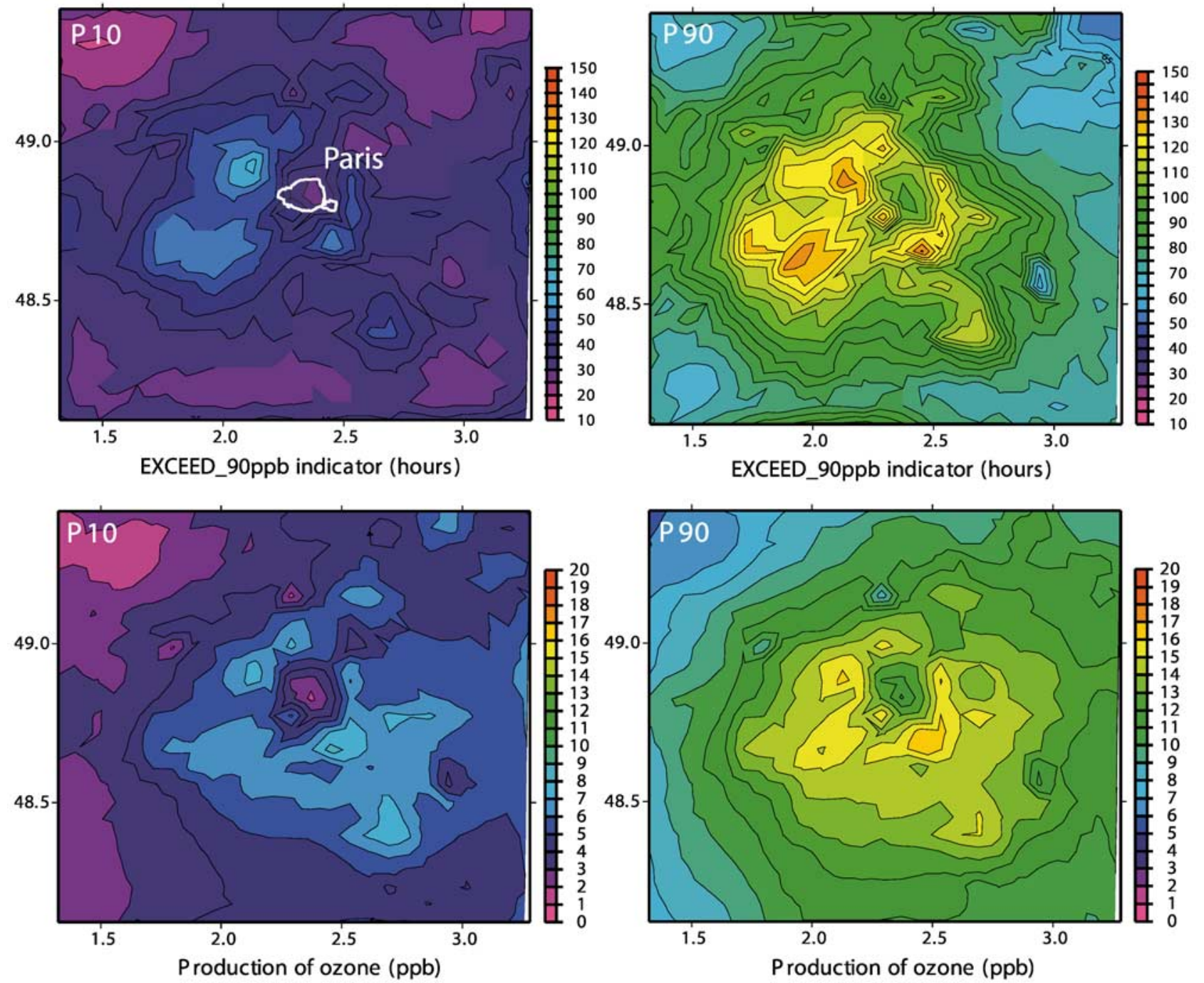

Figure 6. Simulated 10th and 90th percentiles of the production of ozone and of the EXCEED_90ppb indicator averaged or cumulated over summers 1998 and 1999 constrained by observations from the AIRPARIF network.

lation and the simulations with reduced emissions (NOx and $\mathrm{VOC}$, respectively), as well as the relative difference of the simulations with reduced emissions (NOx-VOC). First, when comparing the reference simulation and the simulation with reduced NOx emissions, we notice increases in the ozone concentrations or "neutral" behavior (i.e., less than $2 \mathrm{ppb}$ changes in the $\mathrm{O}_{3}$ concentrations) for the three indicators for nearly all days. These increases are more pronounced in the urban area than outside, probably because of the titration effect. Interestingly, days with positive sensitivity to NOx emission changes in the plume (7 and 8 August 1998, for example) correspond to days with very large ozone concentrations and large temperature (daily max. $>35^{\circ} \mathrm{C}$ ). Indeed, these features increase radical production through ozone photolysis and the VOC/NOx emission ratio due to increased biogenic VOC emissions. Both factors favor more positive sensitivity to NOx emission changes [Sillman, 1999]. Nevertheless, for the large majority of days, NOx emission reductions alone are clearly "counterproductive" or neutral. For many days, the neutral behavior of ozone is directly related to the weak photochemical ozone production so that ozone is not sensitive to emission changes anyway (see Figure 2).

[37] Second, when comparing the reference simulation to the simulation with reduced VOC emissions, we observe a reduction of $\mathrm{O}_{3}$ concentrations which can reach up to $30 \mathrm{ppb}$ for the daily absolute maximum of ozone and/or for the maximum of ozone in Paris (Figure 7). Negative sensitivities are not observed; that is, VOC emission changes are never counterproductive. In general, ozone reduction is larger in the plume than in the urban area, since the ozone production is also stronger in the plume. Again, "neutral" days correspond to weak ozone production. Finally, the comparison between the two simulations with reduced anthropogenic emissions (NOx minus VOC) exhibits an enhancement in the 3 ozone diagnostics for around $60 \%$ of the time. This corresponds to a VOC sensitive chemical regime. A neutral behavior is observed on the remaining $40 \%$ of days. The NOx sensitive chemical regime is never observed. 

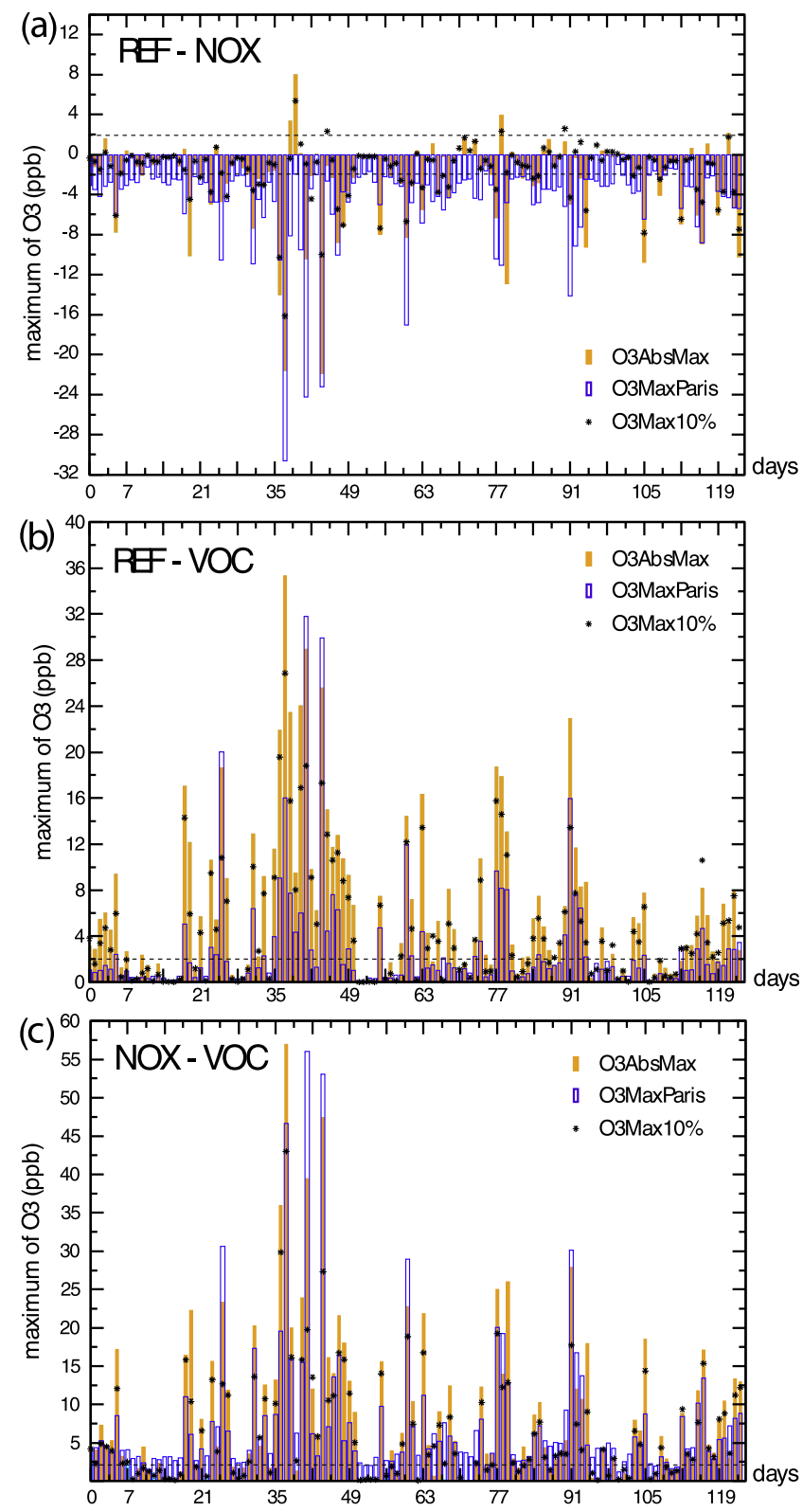

Figure 7. Difference of the daily absolute maximum of ozone (O3AbsMax), of the ozone in the Paris area (O3MaxParis) and of the 10th of the most elevated ozone values (O3Max10\%) between (a) baseline emissions minus reduced NOx emissions $(-30 \%)$, (b) baseline emissions minus reduced VOC emissions $(-30 \%)$, and (c) reduced NOx emissions $(-30 \%)$ minus reduced VOC emissions $(-30 \%)$.

\subsubsection{Bayesian Monte Carlo Approach}

[38] Again, the uncertainty analysis is performed using the BMC framework, and applied to the emission reduction and chemical regimes simulations. Figure 8 presents simulated differences between baseline emissions and emission reduction scenarios. In particular, it shows the 10th, 50th and 90th percentiles (denoted respectively as P10, P50, and P90) of the corresponding CPDFs, again averaged over summers 1998 and 1999. When looking at P50, we first notice the following: (1) When reducing NOx emissions, $\mathrm{O}_{3}$ production is enhanced over the Paris area (around 4$5 \mathrm{ppb}$ ), but also in the surroundings (around $2-3 \mathrm{ppb}$ ); further than $20-40 \mathrm{~km}$ from the Paris city center, $\mathrm{O}_{3}$ production decreases (by up to $1 \mathrm{ppb}$ ); (2) the reduction of VOC emissions leads to a decrease in the P50 of $\mathrm{O}_{3}$ production of around $3 \mathrm{ppb}$ in the Paris area, leveling off as a function of distance from the Paris city center; and (3) finally, when analyzing the spatial distribution of the difference between the two emission reduction scenarios (NOx-VOC), we observe positive values within or near the urban area (VOC sensitive chemical regime). The VOC sensitive chemical regime becomes less pronounced when leaving the Paris city center, and shifts to an intermediate chemical regime (with ozone changes less then $2 \mathrm{ppb}$ ) at about $30 \mathrm{~km}$ distance. However, the NOx sensitive chemical regime is never observed.

[39] Next, we analyze the uncertainty in these results from the P10 and P90 plots in Figure 8. As far as the nature of the chemical regime is concerned, it is always (in the P10, P50 and P90 plots) VOC sensitive over the urbanized area in the center of the domain. However, the spatial extension of the area covered by a VOC sensitive regime (i.e., the frontier to a neutral regime with ozone changes less then $2 \mathrm{ppb}$ ) is rather uncertain. In the P10 plot, the VOC sensitive regime is limited to the central model area (region with a distance of $10-20 \mathrm{~km}$ around Paris downtown), whereas it covers nearly the half of the model domain in the P90 plot. However, even in the P90 plot, a NOx sensitive regime is never observed.

[40] Figure 9 shows CPDFs for differences in the three $\mathrm{O}_{3}$ diagnostics $\left(\mathrm{O}_{3}\right.$ AbsMax, $\mathrm{O}_{3}$ MaxParis, $\mathrm{O}_{3}$ Max $\left.10 \%\right)$ averaged over the two summers when applying emission scenarios: Within the Paris area (O3MaxParis), $\mathrm{O}_{3}$ concentrations are clearly enhanced when NOx emissions are reduced and are decreased when VOC emissions are reduced. Thus the chemical regime is clearly VOC sensitive and the probability to observe a neutral (less than 2 ppb changes) or a NOx sensitive regime is close to zero. CPDFs show further that ozone concentrations in the plume $(\mathrm{O} 3 \mathrm{Max} 10 \%)$ and the absolute maximum of ozone (O3AbsMax) are enhanced by a decrease in NOx emissions with about $80 \%$ chance, but the probability for an opposite behavior remains significant (around 20\%). A decrease in VOC emissions reduces the value of these two indicators, with near zero chance for an opposite behavior. As a consequence, also for plume ozone, the chemical regime is unambiguously VOC sensitive.

\section{Discussion}

[41] In this section, we will first compare the result on the average VOC sensitive chemical regime in the urban area of Paris to earlier results for other urban areas. We will then discuss limitations and the general applicability of the BMC method for other cases.

[42] Previous case studies for other big urban areas showed a VOC sensitive chemical regime for the most cases within the urban areas. Case studies for Los Angeles [Sillman et al., 1997], Nashville [Sillman et al., 1998], New York [Kleinman et al., 2000], Leipzig [Klemm et al., 2000] or Milan [Spirig et al., 2002] all exhibit a VOC sensitive regime. An earlier BMC study for the urban area of Paris [Beekmann and Derognat, 2003], restricted for three days 

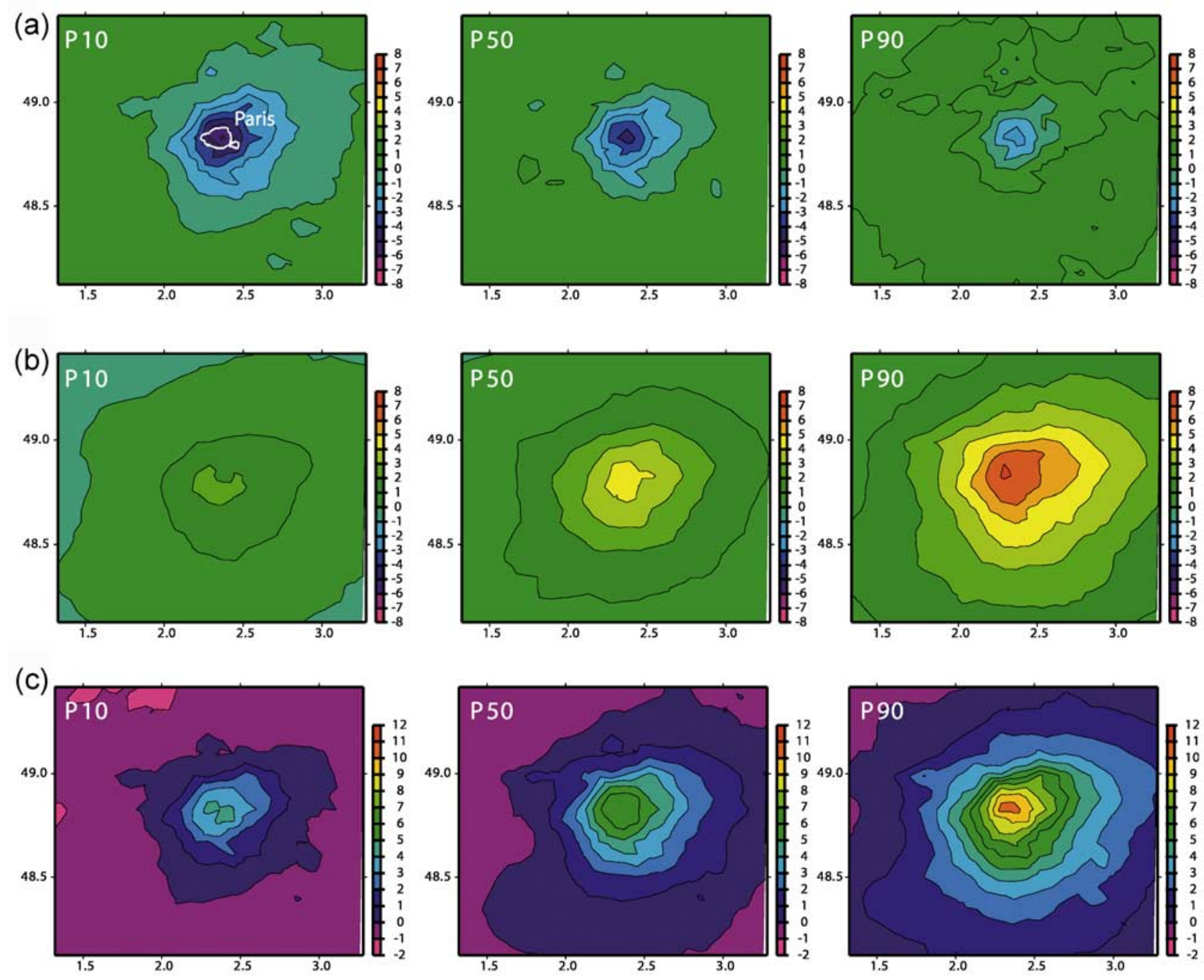

Figure 8. Simulated 10th, 50th and 90th percentiles of the ozone production averaged over summers 1998 and 1999 from constrained Monte Carlo simulations. (a) Baseline emissions minus reduced NOx emissions $(-30 \%)$, (b) baseline emissions minus reduced VOC emissions $(-30 \%)$, and (c) reduced NOx emissions $(-30 \%)$ minus reduced VOC emissions $(-30 \%)$.

with strong photochemical ozone buildup, suggested some variability in the chemical regime (averaged over the whole plume) from one day to another (clear VOC sensitivity for two days, undefined regime for another day). This variability over a 4-month period is confirmed by the present study showing either a VOC sensitive or a neutral chemical regime, but never a NOx-sensitive chemical regime. On the contrary, Atlanta exhibits a different behavior with a NOx sensitive chemical regime due to the high biogenic VOC emissions and high solar radiation intensity [Sillman et al., 1995]. The chemical regime in the ozone plume is more variable. Big urban areas with more than 10 millions of inhabitants (New York, Los Angeles, Paris) exhibit a more VOC-sensitive regime during stagnant days also within the plume, whereas for the smaller towns cited above the chemical regime is variable. Therefore we conclude that large urban areas in temperate latitudes mainly influenced by anthropogenic emissions are controlled by a VOC sensitive chemical regime both within the urban area and within the plume, whereas smaller towns influenced by biogenic VOC emissions and experiencing stronger radiation, are exposed to more variable chemical regimes, and can also be NOx sensitive.

[43] As already pointed out by Deguillaume et al. [2007], the Bayesian Monte Carlo analysis method, as applied here, has several limitations. First, in this study, only the uncertainty in the model input parameters and not that in the model parameterizations themselves has been addressed. Nevertheless, this latter is supposed to be implicit in the former. Uncertainty in the vertical exchange coefficient between model layers partly includes that in the turbulence scheme, uncertainty in rate constants and photolysis frequencies partly includes that in the chemical scheme. Second, uncertainty ranges for input parameters have been chosen as a result of expert judgments as explained by Beekmann and Derognat [2003]. Choices were made in a conservative way, that is they are rather too large than too small. Finally, the dominance of VOC sensitive chemical 
regime is yielded unambiguously by the CPDFs, that these results are not believed to be affected by these methodological limitations. Another type of limitation is that the model input uncertainties are considered as systematic, i.e.,
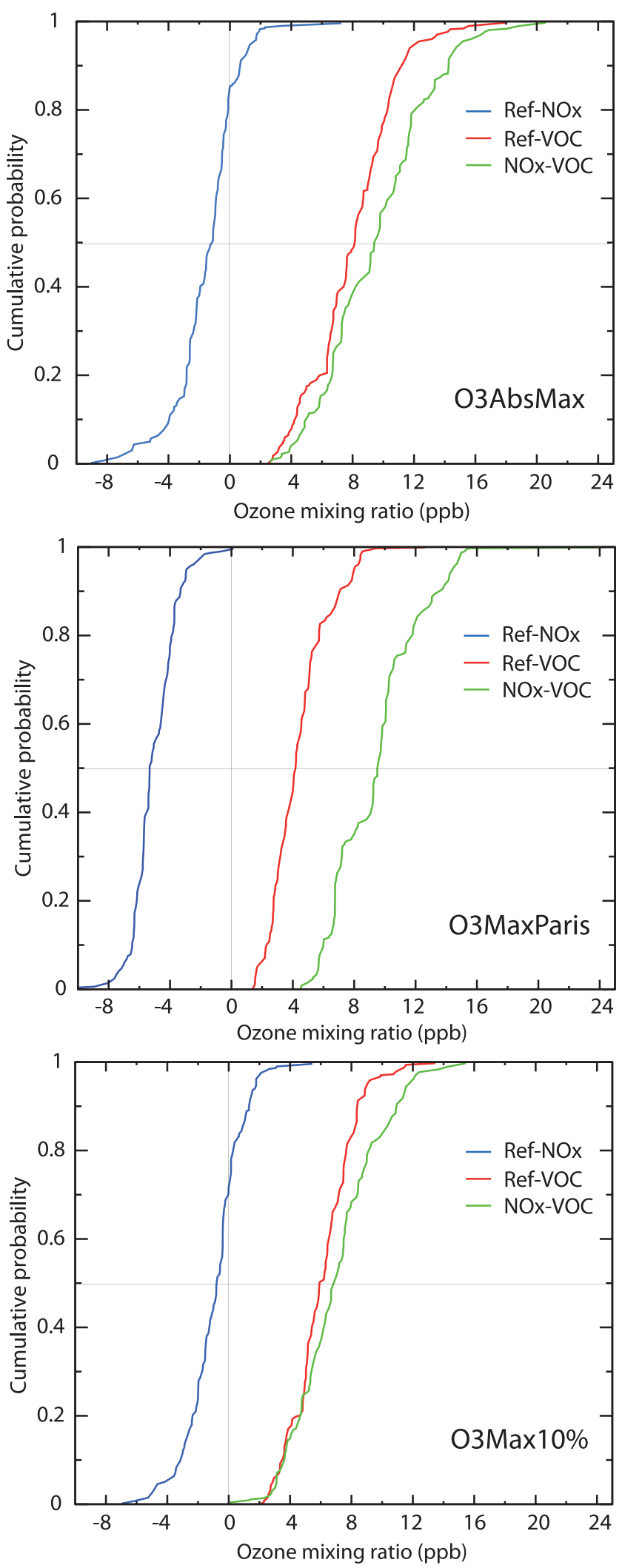

constant for the whole simulation period. As a consequence, the BMC method is applied to quantities temporally averaged over the summers 1998 and 1999. Only the uncertainty in the average chemical regime, and not that for a particular day, is addressed.

[44] The BMC analysis as setup in this work can easily be applied to other urban areas, if the following conditions are fulfilled:

[45] 1. The simulation has to be of sufficiently good quality, especially regarding transport, for which the model has to be capable to reproduce the basic transport patterns. This is certainly easier for urban areas like the Paris one, which are imbedded in a rather flat terrain, and without complex transport patterns.

[46] 2. The measurement network needs to be sufficiently dense, with several urban background sites measuring primary (NO, NOx) and secondary (ozone) pollutants. Additional ozone monitoring sites need to be present in adjacent rural areas, in order to capture the pollution plume and to calculate the ozone background. Clearly, the availability of trace gas measurements ( $\mathrm{NOy}, \mathrm{NOz}, \mathrm{H}_{2} \mathrm{O}_{2}, \ldots$..) that have been traditionally used to determine the chemical regime from observations would allow to further reduce the uncertainty ranges obtained with the BMC method, but these measurements cannot be expected to be available on a continuous basis.

\section{Conclusions}

[47] An uncertainty analysis of ozone buildup in the urban area of Paris and plume, and of its sensitivity to emission changes, has been performed using Bayesian Monte Carlo analysis. In this frame, two summer simulations with the regional chemical transport model CHIMERE were constrained by routine observations $\left(\mathrm{O}_{3}, \mathrm{NOx}\right)$ from the local air quality network AIRPARIF. Several important conclusions were reached:

[48] 1. Simulations performed with the reference model show a major occurrence of ozone plumes in southwestern to southeastern directions downwind the Paris area. The simulated ozone production is on the average about 3-4 ppb within the urban area of Paris, but around $10 \mathrm{ppb}$ in the near surroundings (summing up days with and without plumes). For about $10 \%$ of individual days, maximum ozone concentrations within the domain are larger than $90 \mathrm{ppb}$. The number of hours when ozone concentrations exceed the $90 \mathrm{ppb}$ threshold is around $70 \mathrm{~h}$ for the 4 considered summer months in the west of Paris, illustrating the importance of ozone pollution for air quality management.

[49] 2. It is shown that the Bayesian Monte Carlo method presents an interesting framework to assess and reduce

Figure 9. Cumulative probability density functions from constrained Monte Carlo simulations of the absolute maximum of ozone (O3AbsMax), of the $\mathrm{O}_{3}$ in the Paris area (O3MaxParis), and of the $10 \%$ of the most elevated ozone values (O3Max10\%). Blue indicates baseline emissions minus reduced NOx emissions $(-30 \%)$, red indicates baseline emissions minus reduced VOC emissions $(-30 \%)$, and green indicates reduced NOx emissions $(-30 \%)$ minus reduced VOC emissions $(-30 \%)$. 
model uncertainties, and thus to correct model simulations. Uncertainties in different ozone diagnostics (daily ozone maxima within the urban area, the plume, the domain, averaged over two summers) are significantly reduced (by a factor 1.6 to 1.8) when applying constraints by observations. The $\mathrm{O}_{3}$ concentration in the plume and subsequently also the number of hours of exceeding the $90 \mathrm{ppb}$ air quality threshold are enhanced compared to the reference model. This increase of the $\mathrm{O}_{3}$ concentration in plume is linked to enhancement on VOC emissions.

[50] 3. Bayesian Monte Carlo analysis shows that the chemical regime over urban area (Paris and suburbs) and within the plume is clearly VOC sensitive; that is, VOC emission reductions within the model domain are more favorable than NOx emission reductions to decrease ozone levels. When looking at average ozone production within the model domain, irrespective of the presence of a plume, the chemical regime is always clearly VOC sensitive at least within 10-20 km distance from the Paris center (i.e., within mainly within the urban area). However, the distance of the transition from a VOC sensitive to a neutral chemical regime is highly uncertain.

[51] 4. Our results confirm investigations from case studies, which show VOC sensitive chemical regimes for large urban areas located in temperate latitudes, and with a predominance of anthropogenic over biogenic VOC emissions, such as Los Angeles or New York. However, in general, no uncertainty assessment has been performed for this type of studies. The BMC method setup in this work offers a general and formal framework to address the uncertainty in the chemical regime.

[52] Acknowledgments. The authors gratefully acknowledge the AIRPARIF network (http://www.airparif.asso.fr) which graciously provides the validated observations used for constraining our simulations. This work was supported by a project grant in the frame of the French PRIMEQUAL program (OPTEMI project, Optimization des Emissions par Modélisation Inverse). Paola Formenti (LISA/CNRS) is thanked for careful reading of the paper.

\section{References}

Bascomb, R., P. A. Bromberg, D. L. Costa, R. Devlin, D. W. Dockery, M. W. Frampton, W. Lambert, J. M. Samet, F. E. Speizer, and M. Utell (1996), Health effects of outdoor air pollution, Am. J. Respir. Crit. Care Med., 153, 477-498.

Beekmann, M., and C. Derognat (2003), Monte Carlo uncertainty analysis of a regional-scale transport chemistry model constrained by measurements from the Atmospheric Pollution Over the Paris Area (ESQUIF) campaign, J. Geophys. Res., 108(D17), 8559, doi:10.1029/ 2003JD003391.

Bergin, M. S., and J. B. Milford (2000), Application of Bayesian Monte Carlo analysis to a Lagrangian photochemical air quality model, Atmos. Environ., 34, 781-792.

Deguillaume, L., M. Beekmann, and L. Menut (2007), Bayesian Monte Carlo analysis applied to regional-scale inverse emission modeling for reactive trace gases, J. Geophys. Res., 112, D02307, doi:10.1029/ 2006JD007518.

Derognat, C. (2002), Pollution photo-oxydante à l'échelle urbaine en interaction avec l'échelle régionale, Thèse de doctorat, Univ. Paris 6, Paris.

Derognat, C., M. Beekmann, M. Baeumle, D. Martin, and H. Schmidt (2003), Effect of biogenic volatile organic compound emissions on tropospheric chemistry during the Atmospheric Pollution Over the Paris Area (ESQUIF) campaign in the Ile-de-France region, J. Geophys. Res., 108(D17), 8560, doi:10.1029/2001JD001421.

Kleinman, L. I., P. H. Daum, J. H. Lee, Y. Lee, L. J. Nunnermacker, S. R Springston, L. Newman, J. Weinstein-Lloyd, and S. Sillman (1997), De- pendence of ozone production on NO and hydrocarbons in the troposphere, Geophys. Res. Lett., 24(18), 2299-2302.

Kleinman, L. I., P. H. Daum, D. G. Imre, J. H. Lee, Y.-N. Lee, L. J. Nunnermacker, S. R. Springston, J. Weinstein-Lloyd, and L. Newman (2000), Ozone production in the New York City urban plume, J. Geophys. Res., 105, 14,495-14,512.

Klemm, O., W. R. Stockwell, H. Schlager, and M. Krautstrunk (2000), NO or VOC limitation in East German ozone plumes?, J. Atmos. Chem., 35, $1-18$.

Madronich, S., and S. Flocke (1998), The role of solar radiation in atmospheric chemistry, in Handbook of Environmental Chemistry, edited by P. Boule, pp. 1-26, Springer, Heidelberg, Germany.

Menut, L., et al. (2000), Measurements and modelling of atmospheric pollution over the Paris area: An overview of the ESQUIF project, Ann. Geophys., 18, 1467-1481.

National Research Council (1991), Rethinking the Ozone Problem in Urban and Regional Air Pollution, Natl. Acad. Press, Washington, D. C.

Reynolds, S. D., P. M. Roth, and J. H. Seinfeld (1974), Mathematical modeling of photochemical air pollution-III: Evaluation of the model, Atmos. Environ., 8, 563-596.

Roth, P. M., P. L. W. Roberts, M. K. Liu, S. D. Reynolds, and J. H. Seinfeld (1974), Mathematical modeling of photochemical air pollution. II. A model and inventory of pollutant emissions, Atmos. Environ., 8, 97-130.

Schmidt, H., C. Derognat, R. Vautard, and M. Beekmann (2001), A comparison of simulated and observed ozone mixing ratios for the summer of 1998 in Western Europe, Atmos. Environ., 35, 6277-6297.

Sillman, S. (1999), The relation between ozone, NOx and hydrocarbons in urban and polluted rural environments, Atmos. Environ., 33, 1821-1845. Sillman, S., et al. (1995), Photochemistry of ozone formation in Atlanta, GA: Models and measurements, Atmos. Environ., 29, 3055-3066.

Sillman, S., D. He, C. Cardelino, and R. Imhoff (1997), The use of photochemical indicators to evaluate ozone-NOx-hydrocarbon sensitivity: Case studies from Atlanta, New York and Los Angeles, J. Air Waste Manage. Assoc., 47, 1030-1040

Sillman, S., D. He, M. Pippin, P. H. Daum, J. H. Lee, L. Kleinman, and J. Weinstein-Loyd (1998), Model correlations for ozone, reactive nitrogen, and peroxides for Nashville in comparison with measurements: Implication for $\mathrm{O}_{3}$-NOx-hydrocarbon chemistry, J. Geophys. Res., 103, $22,629-22,644$

Sillman, S., R. Vautard, L. Menut, and D. Kley (2003), $\mathrm{O}_{3}-\mathrm{NO}_{x}-\mathrm{VOC}$ sensitivity and $\mathrm{NO}_{x}$-VOC indicators in Paris: Results from models and Atmospheric Pollution Over the Paris Area (ESQUIF) measurements, J. Geophys. Res., 108(D17), 8563, doi:10.1029/2002JD001561.

Simpson, D. (1995), Biogenic emissions in Europe: 2. Implications for ozone control strategies, J. Geophys. Res., 100(D11), 22,891-22,906.

Simpson, D., Y. Andersson-Sköld, and M. E. Jenkin (1993), Updating the chemical scheme for the EMEP MSC-W oxidant model: Current status, EMEP MSC-W Note 2/93, Norw. Meteorol. Inst., Oslo.

Spirig, C., A. Neftel, L. I. Kleinman, and J. Hjorth (2002), $\mathrm{NO}_{x}$ versus VOC limitation of $\mathrm{O}_{3}$ production in the Po valley: Local and integrated view based on observations, J. Geophys. Res., 107(D22), 8191 , doi:10.1029/2001JD000561.

Tarasson, L., J. E. Jonson, H. Fagerli, A. Benedictow, P. Wind, D. Simpson, and H. Klein (2003), Transboundary acidification and eutrophication and ground level ozone in Europe: Source-receptor relationships, EMEP Status Rep. 1/03, part III, EMEP Meteorol. Synthesizing Cent.-West, Norw. Meteorol. Inst., Oslo.

Troen, I., and L. Mahrt (1986), A simple model of the atmospheric boundary layer: Sensitivity to surface evaporation, Boundary Layer Meteorol., $37,129-148$.

Vautard, R., M. Beekmann, J. Roux, and D. Gombert (2000), Validation of a hybrid forecasting system for the ozone concentrations over the Paris area, Atmos. Environ., 35, 2449-2461.

Vautard, R., et al. (2003), Paris emission inventory diagnostics from ESQUIF airborne measurements and a chemistry transport model, J. Geophys. Res., 108(D17), 8564, doi:10.1029/2002JD002797.

Vautard, R., C. Honoré, M. Beekmann, and L. Rouil (2005), Simulation of ozone during the August 2003 heat wave and emission control scenarios, Atmos. Environ., 39, 2957-2967.

Verwer, J. (1994), Gauss-Seidel iterations for stiff odes from chemical kinetics, SIAM J. Sci. Comput., 15, 1243-1250.

M. Beekmann and L. Deguillaume, Laboratoire Inter-Universitaire des Systèmes Atmosphériques, UMR CNRS 7583, Universités Paris 7 et Paris 12, F-94010 Créteil Cedex, France. (deguillaume@lisa.univ-paris12.fr)

C. Derognat, Aria Technologies SA, F-92100 Boulogne Billancourt, France. 